\title{
The tolerance of oil palm (Elaeis guineensis) seedlings to Al stress is enhanced by citric acid and natural peat water
}

\author{
AGUS NUR HIDAYAH ${ }^{1}$, SUDIRMAN YAHYA ${ }^{2}$, DIDY SOPANDIE ${ }^{2, \boldsymbol{v}}$ \\ ${ }^{1}$ Program of Agronomy and Horticulture, Graduate School, Institut Pertanian Bogor. Jl. Meranti, Kampus IPB Dramaga, Bogor 16680, West Java, Indonesia \\ ${ }^{2}$ Department of Agronomy and Horticulture, Faculty of Agriculture, Institut Pertanian Bogor. Jl. Raya Dramaga, Kampus IPB Dramaga, Bogor 16680 , \\ West Java, Indonesia. Tel./fax.: +62-251-8629353, ”email: d.sopandie20 @ gmail.com
}

Manuscript received: 19 August 2020. Revision accepted: 26 September 2020.

\begin{abstract}
Hidayah AN, Yahya S, Sopandie D. 2020. The tolerance of oil palm (Elaeis guineensis) seedlings to Al stress is enhanced by citric acid and natural peat water. Biodiversitas 21: 4850-4858. Management technology on soil containing high levels of Aluminum (Al) toxicity is still needed to be developed so that the growth and development of plants will be optimum. The aims of the research were to investigate the response of oil palm seedlings (Elaeis guineensis Jacq.) toward aluminum stress, and to evaluate the effects of several exogenous compounds to improve the tolerance of oil palm. The research was conducted from September 2018 to March 2019 at PT Gunung Sejahtera Ibu Pertiwi, Central Kalimantan. This research consisted of two nutrient culture experiments, namely: Al toxicity on oil palms seedlings and the role of various exogenous compounds to improve plant tolerances. The results revealed that the solution at concentrations of $400 \mu \mathrm{M}, 800 \mu \mathrm{M}$, and $1600 \mu \mathrm{M}$ of Al significantly inhibited root growth, increased MDA levels, decreased the photosynthesis rate, activity of CAT and APX. Therefore, a solution at concentration of $400 \mu \mathrm{M}$ of Al can be used as the selection level of Al tolerant oil palm varieties on nutrient culture. Ethephon at concentrations of $25 \mathrm{ppm}, 50 \mathrm{ppm}$, and 100 ppm inhibited root and shoot growth, increased MDA levels but reduced the photosynthesis rate, chlorophyll content, APX, and CAT activity. Addition of 25 ppm and 50 ppm of citric acid, $200 \mathrm{ppm}$ and $300 \mathrm{ppm}$ of peat water significantly increased root length, root dry weight, photosynthesis rate, chlorophyll content, carotenoids, CAT, and APX activities as MDA levels decreased. Addition of citric acid and peat water enabled seedlings of oil palm to improve their tolerance to $\mathrm{Al}$ stress on nutrient culture.
\end{abstract}

Keywords: CAT activity, chlorophyll content, MDA level, photosynthesis rate, root growth

Abbreviations: APX: ascorbate peroxidase, CA: citric acid, CAT: catalase, DAT: day after treatment, Et: ethephon, HAT: hour after treatment, MDA: malondialdehyde, PW: peat water

\section{INTRODUCTION}

One of the constraints in oil palm (Elaeis guineensis Jacq.) cultivation is the poor management technology of plant cultivation in marginal land, thus the plants productivity is under their potential. The upland soil in Indonesia is dominated by acid mineral soil approximately 107.36 million ha $(74.31 \%)$ (Ritung et al. 2015). This type of soil has the characteristics i.e low $\mathrm{pH}$ and cation exchange capacity, low base saturation and $\mathrm{C}$ organic, high $\mathrm{Al}$ saturation, high Fe and Mn content, subject to erosion, and deficient on macronutrients (especially $\mathrm{P}, \mathrm{K}, \mathrm{Mg}$, and Ca) (Sopandie 2014). Efforts to improve cultivation on acid soil, however, still use soil ameliorant such as agricultural lime and dolomite fertilizer (Lubis 2008), which needs a lot of input per acre of land, and it is costly.

The diversity of oil palm in Indonesia is quite high, it is proven that 53 varieties have been registered with the Indonesian Ministry of Agriculture (Direktorat Perbenihan Perkebunan 2020). In addition, Setiawan (2017) stated that the Indonesian oil palm consortium in collaboration with the Government had introduced them from Cameroon in 2008 and from Angola in 2010 to increase their source of diversity. The tolerance level of oil palm varieties to $\mathrm{Al}$ stress and acid soils varies widely. Although Corley and
Thinker (2015) pointed out that oil palm grows well in acid soils and able to accumulate of $\mathrm{Al}$ around $200 \mathrm{ppm}$ on leaves and $600 \mathrm{ppm}$ on roots, but lateral root growth is reduced at high aluminum levels and low $\mathrm{pH}$ (Cristancho et al. 2011). From those upland soil characteristics. high $\mathrm{Al}$ concentrations in soils are the main limiting factors for plant growth and development. Al toxicity reduced leaf size, plant height, and total dry weight of oil palm seedlings (Ratnasari et al. 2016), primary root length, and sugar content in shoots and roots (Supena et al. 2014). In fact, one of the varieties planted in oil palm land with an $\mathrm{Al}$ saturation above $75 \%$ shows high flower and fruit abortion so that the productivity achievement is only about $70 \%$ of its potential. Therefore, it is necessary to develop more adaptive varieties through rapid and precise selection methods.

Plants treated with $\mathrm{Al}$ have a natural tolerance mechanism but their expression is often slow, so it is necessary to accelerate their internal mechanism through induction of signal transduction. One of the Al-tolerant varieties is Simalungun DxP (Supena et al. 2014), but its tolerance could possibly be increased by adding exogenous compounds. Several studies revealed that some chemical compounds could induce the signal transduction in plant which is thought to have a contribution to the change of 
gene expression, that leads to the increase of activity of several antioxidant enzymes such as APX, CAT, and GPX. These are very important enzymes in protecting the cell from oxidative damage by reactive oxygen species (ROS) resulted from Al toxicity. There are several chemical compounds that have induced the tolerance to Al stress, such as calcium on pepper plant (Yang 2014), citric acid on wheat plant (Sadak and Orabi 2015), ethephon on Kentucky bluegrass seedlings (Zhang et al. 2018), and peat water on Aloe vera (Chotimah et al. 2013). Sopandie (2014) pointed out that a short-term problem-solving approach can be through tolerance induction by using plant growth regulators (PGRs), hormone, osmoprotectant, $\mathrm{Ca} 2+$, and $\mathrm{Si}$. Induction of tolerance can be defined as a complex change, involving a variety of different metabolic pathways until cellular and molecular level when it is responding to certain stress (Onaga and Wydra 2016).

Levitt (1980) mentioned that exogenous compounds (PGRs, hormone, osmoprotectant, $\mathrm{Ca} 2+$ ) could influence the transduction signal process that is involved in the gene expression change when the plants are stressed. This change will induce the activities of antioxidant enzymes, such as CAT, APX, and GPX that play a role in ROS scavenging, so that it can reduce MDA accumulation (Apel and Hirt 2004). The concept of making use of exogenous compounds in oil palm cultivation is expected to become an initial step to overcome aluminum stress. The aims of the research were to obtain a quick selection method for the aluminum stress-tolerant on oil palm at the seedling phase, oil palm growth, and physiological responses to stress and to evaluate the effects of several exogenous compounds to improve the tolerance of oil palm.

\section{MATERIALS AND METHODS}

\section{Plant materials}

Simalungun DxP variety seedlings obtained from the Indonesian Palm Oil Research Institute (IOPRI, Medan, Indonesia) were selected for their shape, color, and size. Planting was done by inserting a shell sprout into the planting hole where the radicle tip facing down and plumula to the top and then covered again with sand. After planting, media was watered with water in advance as much as $100 \mathrm{~mL} /$ polybag. Ten-week-old seedlings with similar growth were selected and transplanted into the hydroponic system with nutrient solutions (Sopandie, 1990). Nutrient culture composition as follows: $1.5 \mathrm{mM} \mathrm{Ca}$ $\left(\mathrm{NO}_{3}\right)_{2} .4 \mathrm{H}_{2} \mathrm{O}, 1.0 \mathrm{mM} \mathrm{NH} \mathrm{NO}_{3}, 1.0 \mathrm{mM} \mathrm{KCl}, 0.4 \mathrm{mM}$ $\mathrm{MgSO}_{4} .7 \mathrm{H}_{2} \mathrm{O}, 1.0 \mathrm{mM} \mathrm{KH_{2 }} \mathrm{PO}_{4}, 0.068 \mathrm{mM} \mathrm{Fe}\left(\mathrm{C}_{6} \mathrm{H}_{7} \mathrm{O}_{7}\right)$, $0.50 \mathrm{ppm} \mathrm{MnSO}_{4} . \mathrm{H}_{2} \mathrm{O}, 0.02 \mathrm{ppm} \mathrm{CuSO}_{4} .5 \mathrm{H}_{2} \mathrm{O}, 0.05 \mathrm{ppm}$ $\mathrm{ZnSO}_{4} .7 \mathrm{H}_{2} \mathrm{O}, \quad 0.5 \mathrm{ppm} \quad \mathrm{H}_{3} \mathrm{BO}_{3}$ dan 0.01 ppm $\mathrm{NH}_{6} \mathrm{Mo}_{7} \mathrm{O}_{24} .4 \mathrm{H}_{2} \mathrm{O}$. Nutrient solution was renewed every 5 days and the $\mathrm{pH}$ was kept constant $(4.0 \pm 0.1)$ every 2 days though addition of $0.3 \mathrm{mM}$ sodium hydroxide $(\mathrm{NaOH})$ or $0.05 \mathrm{M}$ hydrochloric acid $(\mathrm{HCl})$, as required. This research was conducted at the Experimental Farm, PT Gunung Sejahtera Ibu Pertiwi, Central Kalimantan, Indonesia in shade house for 6 months (September 2019 - March 2020).

\section{Procedures}

Aluminum toxicity to the growth of oil palm seedling stage on nutrient culture

This experiment was arranged in a completely randomized design with various aluminum concentrations $(0 \mu \mathrm{M}, 100 \mu \mathrm{M}, 200 \mu \mathrm{M}, 400 \mu \mathrm{M}, 800 \mu \mathrm{M}$ and $1600 \mu \mathrm{M})$ with 3 replications. The addition of $\mathrm{Al}$ was done when transplanted and renewed of nutrient solution every 5 days. Determination of photosynthesis rate, malondialdehyde (MDA) level, ascorbate peroxidase (APX) enzyme activity, catalase (CAT) enzyme activity were carried out at 3 HAT (hours after treatment), 7 HAT, 24 HAT, and 72 HAT while growth measurements (root length, plant height, number of leaves, diameter of stem, root and shoot dry weight ) at 30 days after treatment (DAT).

\section{The effects of various exogenous compounds in alleviating} the adverse effect of Al on oil palm seedlings

This experiment used a completely randomized design with the following treatments: $0 \mu \mathrm{M} \mathrm{Al}$ (control), $400 \mu \mathrm{M}$ $\mathrm{Al}, \mathrm{Al}+$ Ethephon (Et) $25 \mathrm{ppm}, \mathrm{Al}+\mathrm{Et} 50 \mathrm{ppm}, \mathrm{Al}+\mathrm{Et}$ $100 \mathrm{ppm}, \mathrm{Al}+$ citric acid (CA) $25 \mathrm{ppm}, \mathrm{Al}+\mathrm{CA} 50 \mathrm{ppm}$, $\mathrm{Al}+\mathrm{CA} 100 \mathrm{ppm}, \mathrm{Al}+$ peat water (PW) $100 \mathrm{ppm}, \mathrm{Al}+$ PW 200 ppm, Al + PW 300 ppm with 3 replications. Natural peat water is peat water from the peatlands of Bereng Bengkel, Central Kalimantan, Indonesia. The Al concentration used $400 \mu \mathrm{M}$ (based on the results of $\mathrm{Al}$ toxicity experiments) and all treatments were given during transplanting and renewal of nutrient solutions every 5 days for new ten-weeks-old seedlings. Determination of MDA levels, APX, and CAT enzyme activity was done at 1 DAT and 3 DAT, while growth measurements (root length, plant height, number of leaves, diameter of stem, root and shoot dry weight, photosynthesis rate, contents of chlorophyll, carotenoid, and anthocyanin) at 30 DAT.

\section{Growth measurements}

Root length and plant height are recorded before transplanting into nutrient solution. Then, the root length, plant height, number of leaves, diameter of stems was measured at 30 DAT. Diameter of stem was measured using a caliper at the base of the stem. Roots and shoots were separated for fresh weight determination. All plant parts were washed in double-distilled water and dried in an oven at $70{ }^{\circ} \mathrm{C}$ for $10 \mathrm{~h}$ and the dry weights recorded with an electronic balance. The rate of photosynthesis was measured on the third leaf using CI-340 Handheld Photosynthesis System in open system mode according to schedule. Whereas the contents of chlorophyll (Chl), carotenoid, and anthocyanin in the third leaf were determined following the Sims and Gamon (2002) method. The third leaf sample was weighed $0.02 \mathrm{~g} \pm 0.005 \mathrm{~g}$ and recorded. Mashed fresh leaf samples, added with acetone tris $2 \mathrm{~mL} \mathrm{85:15} \mathrm{( \% ),} \mathrm{and} \mathrm{centrifuged} \mathrm{(14000} \mathrm{rpm,} \mathrm{for} 10$ minutes). Then, the supernatant $(1 \mathrm{~mL})$ was added with acetone tris $(3 \mathrm{~mL})$ and mixed evenly. Absorbance of the mixture is measured at wavelength 470, 537, 647, and 663 $\mathrm{nm}$, measured with UV-VIS spectrophotometer. The result expressed as mol per $100 \mathrm{~g}$ wet weight (mol $\left.100 \mathrm{~g}^{-1}\right)$. 


\section{MDA level and CAT activity}

Determination of MDA levels and CAT activity used the method of Chen and Zang (2016). The first step, prepare the crude protein/ enzyme extract. As much as 0.2 $\mathrm{g}$ of the fresh leaf was weighed and ground them with a mortar and pestle in liquid nitrogen. The leaf powder homogenized by adding $3 \mathrm{ml}$ of $100 \mathrm{mM}$ PBS buffer. The homogenate assigned to two $1.5 \mathrm{ml}$ centrifuge tubes and centrifuge at $10,000 \mathrm{xg}$ for $20 \mathrm{~min}$ at $4{ }^{\circ} \mathrm{C}$. The supernatant transferred to new centrifuge tubes for further analysis. The concentration of crude protein in the supernatant measured with Analytik Jena ScanDrop 250 by a spectrophotometric method with Formula Warburg-Christian (protein): protein concentration $(\mathrm{mg} / \mathrm{ml})=1.55 \times \mathrm{A} 280-0.76 \times \mathrm{A} 260$. For MDA assay, add $100 \mu \mathrm{L}$ extract and $1 \mathrm{~mL} 0.25 \%$ thiobarbituric acid (TBA) were mixed and heated at $100{ }^{\circ} \mathrm{C}$ for $15 \mathrm{~min}$, then quickly cooled in an ice bath ( $\pm 5 \mathrm{~min}) .1$ $\mathrm{mL} 0.25 \%$ TBA solution with $100 \mu \mathrm{L} 100 \mathrm{mM}$ PBS (pH 7.8) serves as a reference. The absorbance of $200 \mu \mathrm{L}$ supernatant was measured at $532 \mathrm{~nm}$ and $600 \mathrm{~nm}$ with Analytik Jena ScanDrop 250 respectively. The MDA level was expressed in nmol $\mathrm{mg}^{-1}$ protein. Then for CAT assay, the reaction solution prepared by adding $77.5 \mu \mathrm{L} 30 \%$ $\mathrm{H}_{2} \mathrm{O}_{2}$ in $50 \mathrm{~mL} 100 \mathrm{mM}$ PBS (pH 7.0) (for 50 reactions). Add $50 \mu \mathrm{L}$ crude enzyme and $1 \mathrm{~mL}$ reaction solution into the cuvette, and immediately record the dynamic absorbance at $240 \mathrm{~nm}$ with Analytik Jena ScanDrop 250 at every $15 \mathrm{sec}$ for $1 \mathrm{~min}$, looking for the steady average alteration. Reaction solution with $50 \mu \mathrm{L} 100 \mathrm{mM}$ PBS (pH 7.8) serves as a reference. The CAT activity was expressed in unit $\mathrm{mg}^{-1}$ protein.

\section{APX activity}

Activity of APX was determined by the method of Nakano and Asada (1981) by recording the decrease in absorbance of ascorbate at $290 \mathrm{~nm}$. The assay mixture contained phosphate buffer $(50 \mathrm{mM}, \mathrm{pH} 7.0), 0.1 \mathrm{mM}$ EDTA, $0.5 \mathrm{mM}$ ascorbate, $0.1 \mathrm{mM} \mathrm{H}_{2} \mathrm{O}_{2}$, and the enzyme extract. APX activity was calculated by using the extinction coefficient $2.8 \mathrm{mM}^{-1} \mathrm{~cm}^{-1}$. One unit of the enzyme is the amount necessary to decompose $1 \mu \mathrm{mol}$ of substrate per min at $25^{\circ} \mathrm{C}$. The APX activity was expressed in umol $\mathrm{min}^{-1} \mathrm{mg}^{-1}$ protein.

\section{Data analysis}

The data were subjected to analysis of variance (ANOVA) and for mean value comparisons by Duncan Multiple Range Test were evaluated where $\mathrm{P}<0.05$ was considered significant. Data analysis used the statistical program Genstat v19.1.0.21390 and the graph reproduced by software Microsoft excel 2010.

\section{RESULTS AND DISCUSSION}

\section{Toxicity and tolerance of aluminum in growth of oil palm seedling}

Al stress inhibited the seedlings growth, including root length, plant height, dry weight of root and shoot, except the leave number, and stem diameter at 30 DAT (Table 1).
Application of 100 and $200 \mu \mathrm{M} \mathrm{Al} \mathrm{did} \mathrm{not} \mathrm{affect} \mathrm{root}$ length, but $400 \mu \mathrm{M} \mathrm{Al}$ treatment reduced the root length by about $33.9 \%$, and at higher concentration, the obstacle on root length becomes bigger. It can be seen that with 200 $\mu \mathrm{M} \mathrm{Al}$ treatment, plant height was decreased, and with 400 $\mu \mathrm{M}$ Al treatment the decrease was the biggest, about 31.4 $\%$. Dry weight of root was not affected by 100 and $200 \mu \mathrm{M}$ Al treatments, but $400 \mu \mathrm{M} \mathrm{Al}$ decreased root dry weight about $32.75 \%$. All Al treatments reduced shoot dry weight, the higher $\mathrm{Al}$ concentration the bigger the decrease (Table 1). Based on these results, $400 \mathrm{uM}$ concentration of $\mathrm{Al}$ was determined as the appropriate concentration to be used in selection of oil palm seedlings tolerance to Al toxicity in nutrient culture. Sopandie (2014) pointed out that the best indicator to differentiate plant resistance to $\mathrm{Al}$ toxic is the value of root growth resistance. The root apex is the critica1site for A1 toxicity and genes for A1 tolerance are likely to be expressed (Delhaize and Ryan 1995). The root apex (root cap, meristem, and elongation zone) accumulates more $\mathrm{Al}$ and attracts greater physical damage than the mature root tissues. The characteristic of root length has a positive correlation with the result of $\mathrm{Al}$ stress (Panda et al. 2009). Some studies on oil palm seedlings concluded that $\mathrm{Al}$ stress has inhibited root growth (Mendez et al. 2014; Christanco et al. 2011; Marlina et al. 2017) and reduced total dry weight (Christanco et al. 2011; Marlina et al. 2017). Rout et al. (2001) mentioned that $\mathrm{Al}$ interferes with cell division in roots, decreases root respiration and uptake and use of water and nutrients, particularly calcium and phosphorous and metabolic pathway. Inhibition of root division was due to the binding of $\mathrm{P}$ at DNA by $\mathrm{Al}$ that enters the cell nucleus of root tip so that the DNA activities decline, and cell division is hampered (Rout et al. 2001). The selection of oil palm seedlings tolerant $\mathrm{Al}$ can be performed under $400 \mu \mathrm{M} \quad \mathrm{Al}$ condition since this concentration showed inhibition in root length, root and shoot dry weight.

\section{Effects of aluminum on photosynthetic rate, organic compound and enzyme activity of oil palm seedlings}

Figure 1 shows the effect of $\mathrm{Al}$ on photosynthetic rate, MDA content, CAT, and APX activities in oil palm seedlings. Al stress has brought about the decrease in the rate of photosynthesis, the effect of which increased with increasing $\mathrm{Al}$ concentration, and the length of time of exposure (Figure 1.A). Proklamasiningsih et al. (2012) and Marlina et al. (2017) have also shown the inhibition effect of Al on photosynthesis rate in oil palm. They have conveyed that the decrease in photosynthesis rate was thought to be due to declines in chlorophyll content (Yang et al. 2015). The inhibition of photosynthetic rate could also be associated with the inhibition of electron transport in photosystem II (Jiang et al. 2009).

Al stress significantly raised MDA content in all $\mathrm{Al}$ concentrations, compared to control, and it keeps increasing as the Al concentration increases (Fig 1B). The activity of CAT enzyme increased significantly in all $\mathrm{Al}$ treatments starting at $3 \mathrm{HAT}$ and $7 \mathrm{HAT}$ then decreased at 24 HAT and 72 HAT (Figure 1C). The same pattern has also occurred in APX, the activity of this enzyme increased 
following the increase in $\mathrm{Al}$ concentration applied, starting at 3 HAT and 7 HAT then decreased dramatically at 24 HAT and 72 HAT (Figure 1D). Panda et al. (2009) mentioned that $\mathrm{Al}$ stress has caused lipid peroxide in plasma membrane so the production of ROS rises. Yamamoto et al. (2001) pointed out that MDA is one of the end products of lipid peroxide that accumulates when the plant is exposed to oxidative stress; the accumulation of MDA in tissue is widely used to estimate cell damage. However, plants have a complex antioxidant system for ROS scavenging, in which specific enzymes act to neutralize the action of free radicals (Miller et al. 2010). When plants are exposed to $\mathrm{Al}$ stress, they will produce antioxidants such as superoxide dismutase (SOD), glutathione peroxide (GPX), CAT, and APX (Shahnawaz and Sanadhya 2017). The magnitude of enzyme antioxidant production and the degree of activity of these enzymes can be used in the selection of genotypes that are susceptible and tolerant to abiotic stress (Kusvuran et al. 2016). Our current results showed that when the seedlings were exposed to Al stress, the increase of enzymes antioxidant activity occurred at 3 HAT and 7 HAT, then decreased dramatically at 24 HAT and 72 HAT, indicating that the increase in enzyme activity can be attributed to the quick response to $\mathrm{Al}$ stress at 3 until 7 hours after exposurement of $\mathrm{Al}$, while at 24 and 72 hours a steadystate condition has achieved. Exposure oil palm seedling to Al stress caused the decrease in rate of photosynthesis, increase MDA levels, followed by the increase of CAT and APX enzyme activity.

Table 1. Effect of $\mathrm{Al}$ treatment to root length, plant height, number of leaves, diameter of stem, roots and shoots dry weight of oil palm seedlings at 30 DAT

\begin{tabular}{|c|c|c|c|c|c|c|}
\hline \multirow[b]{2}{*}{ Concentrations of $\mathrm{Al}(\boldsymbol{\mu M})$} & \multirow[b]{2}{*}{ RL (cm) } & \multirow[b]{2}{*}{ PH (cm) } & \multirow[b]{2}{*}{ NL } & \multirow[b]{2}{*}{ DS (cm) } & \multicolumn{2}{|c|}{ Dry weight (g) } \\
\hline & & & & & Roots & Shoots \\
\hline 0 & $34.63 \mathrm{a}$ & $36.90 \mathrm{a}$ & $4.33 \mathrm{a}$ & $1.03 \mathrm{a}$ & $0.58 \mathrm{a}$ & $2.33 \mathrm{a}$ \\
\hline 100 & $33.00 \mathrm{a}$ & $34.27 \mathrm{a}$ & $4.67 \mathrm{a}$ & $1.10 \mathrm{a}$ & $0.57 \mathrm{a}$ & $1.76 \mathrm{~b}$ \\
\hline 200 & $34.63 \mathrm{a}$ & $30.30 \mathrm{~b}$ & $4.00 \mathrm{a}$ & $1.00 \mathrm{a}$ & $0.51 \mathrm{ab}$ & $1.39 \mathrm{c}$ \\
\hline 400 & $24.70 \mathrm{~b}$ & $25.30 \mathrm{c}$ & $4.33 \mathrm{a}$ & $0.97 \mathrm{a}$ & $0.39 \mathrm{bc}$ & $1.24 \mathrm{~cd}$ \\
\hline 800 & $20.37 \mathrm{c}$ & $26.93 \mathrm{c}$ & $4.67 \mathrm{a}$ & $0.97 \mathrm{a}$ & $0.34 \mathrm{c}$ & $1.01 \mathrm{~d}$ \\
\hline 1600 & $19.73 \mathrm{c}$ & $26.20 \mathrm{c}$ & $4.33 \mathrm{a}$ & $0.93 \mathrm{a}$ & $0.31 \mathrm{c}$ & $0.98 \mathrm{~d}$ \\
\hline
\end{tabular}

Note: The numbers followed by the same letters in the same column show no significant difference based on DMRT at the level $\alpha$ : $5 \%$; $\mathrm{DAT}=$ day after treatment; $\mathrm{RL}=$ root length; $\mathrm{PH}=$ plant height; $\mathrm{NL}=$ number of leaves; $\mathrm{DS}=$ diameter of stem

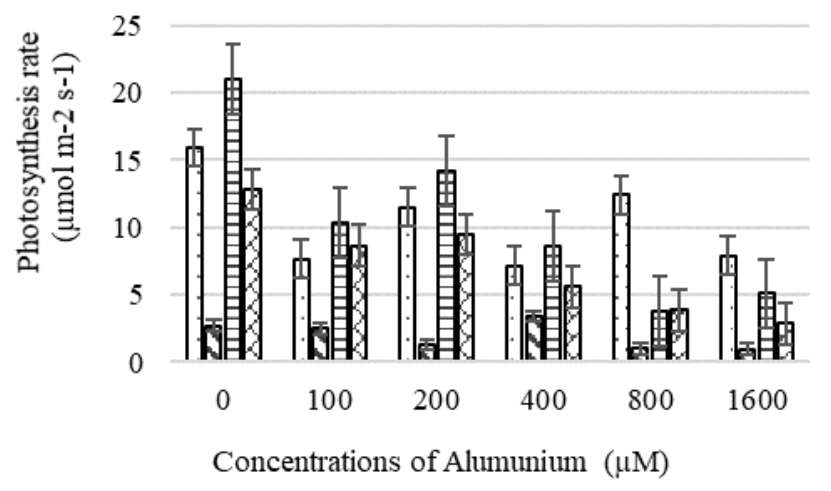

口3 HAT 口7HAT घ24 HAT $\square 72 \mathrm{HAT}$

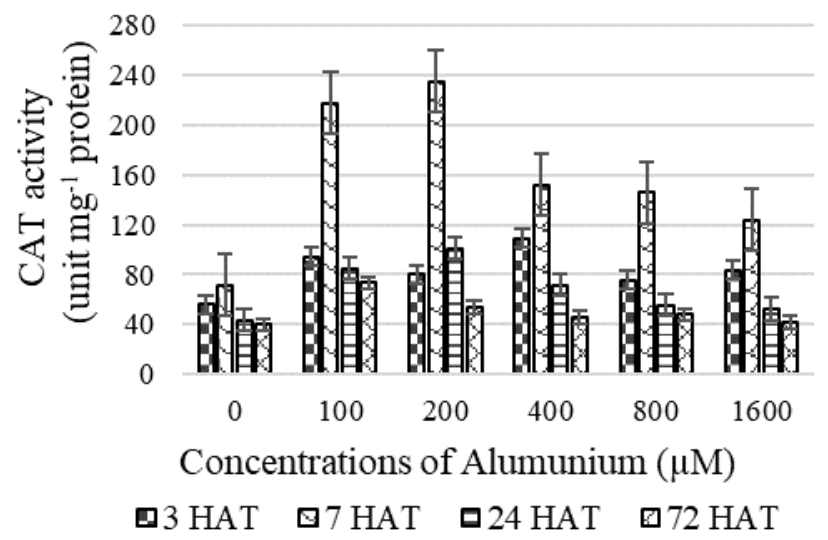

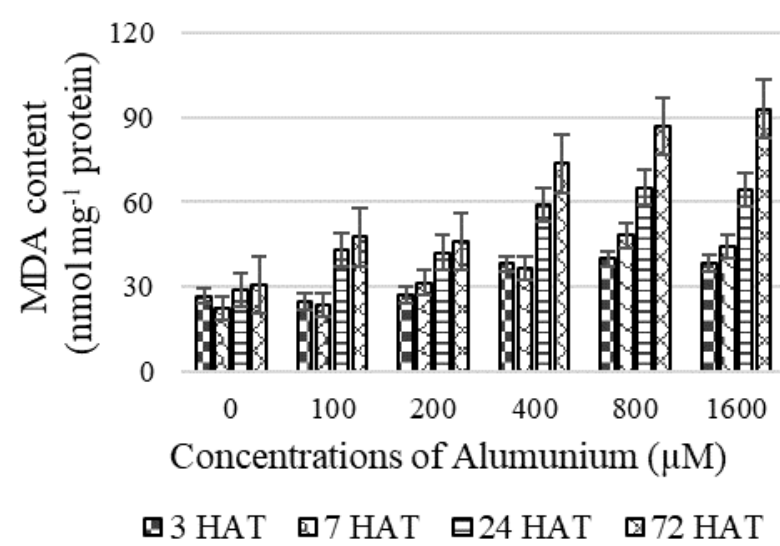

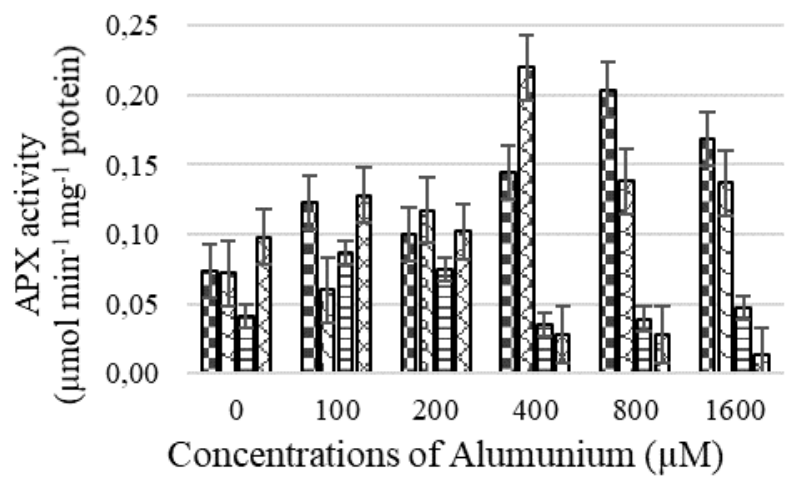

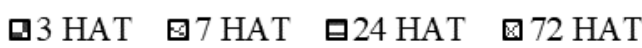

Figure 1. The effect of $\mathrm{Al}$ on photosynthetic rate (A), MDA content (B), CAT (C), and APX (D) activities; HAT = hour after treatment. The bars represent the standard error of the mean 


\section{Effects of various exogenous compounds in growth of oil palm seedlings exposed to Aluminum stress}

Table 2 showed that $400 \mu \mathrm{M} \mathrm{Al}$ inhibited root length, dry weight of root, and shoot drastically at 30 DAT. There was no adverse effect of $\mathrm{Al}$ on plant height, number of leaves, and diameter of stem. In general, except ethephon, the application of citric acid and peat water in some extents could reduce the adverse effects of $\mathrm{Al}$, so that seedlings were able to obtain recovery, although not fully recovered. The results of the experiment showed that ethephon treatment actually worsened the growth of palm oil seedlings after exposure to $\mathrm{Al}$, as indicated by a greater decrease in root length, root dry weight, and shoot dry weight. There was relatively no change in plant height, number of leaves and stem diameter of seedlings after exposurement to high concentration of $\mathrm{Al}$ and application of ethephone. According to Sharma et al. (2019), ethylene, plays a crucial role in ameliorating the harmful effects of these abiotic stress conditions like temperature, drought, heavy metals, and salt. Exposure of tobacco protoplasts to ethephon and ACC led to activation of a plasma membrane cation channel that was permeable to $\mathrm{Ba}(2+), \operatorname{Mg}(2+)$, and $\mathrm{Ca}(2+)$, and inhibited by $\mathrm{Al}(3+)$ (Zhao et al. 2007). Kopittke (2016) pointed out that the production of ethylene and auxin seems to be a component of a plant-response to toxic $\mathrm{Al}$, resulting in cell wall modification or regulation of organic acid release. Yu et al. (2019) revealed that $0.1 \mu \mathrm{M}$ ethrel (ethylene donor) treatment has a maximum biological effect on promoting the adventitious rooting in cucumber under salt stress. However, Sun et al. (2016) pointed out that Al-triggered ethylene acts as a signaling molecule with impacts on auxin biosynthesis and distribution in roots, especially in the root transition zone, and thereby inhibits root growth.

There was an alleviating effect of Al toxicity on root growth due to the application of 25 and $50 \mathrm{ppm}$ of citric acid, in which citric acid tremendously increased the root length and root dry weight, although root growth recovery was not fully. The effect of citric acid on those concentrations did not occur in shoot dry weight. Citric acid at a concentration of $100 \mathrm{ppm}$ did not have a positive effect on the recovery of seedlings growth after exposure to Al. The research results of Hongyu et al. (2018) also revealed exogenous citric acid could effectively alleviate the toxicity of aluminum on P. massoniana seedlings, and it had a better effect on aluminum-sensitive variety than aluminum-resistant variety. $\mathrm{Hu}$ et al. (2016) revealed that exogenous citric acid application may alleviate growth and physiological damage caused by high temperature. Li et al. (2009) pointed out that citrate is considerably more effective as an $\mathrm{Al}$ chelator than is malate. Chotimah et al. (2013) pointed out that application of peat water increased frond number, frond width, and decreased Al-frond.

Table 2 indicates that not all concentrations of peat water have a positive effect on increasing the tolerance of oil palm seedlings to the adverse effects of Al, i.e. only 200 ppm peat water showed a beneficial impact on seedlings growth. Adding $200 \mathrm{ppm}$ peat water into nutrient culture containing high concentration of $\mathrm{Al}$ enabled seedlings to grow normally under $\mathrm{Al}$ stress conditions, as indicated by root length, root dry weight, and shoot dry weight which were relatively similar to the control condition without $\mathrm{Al}$. There was no so much information obtained about the effect of peat water on increasing tolerance to Al toxicity in oil palm seedlings. The peat water there was $24.56 \mathrm{ppm}$ of the total carboxylic acids and $12.72 \mathrm{ppm}$ of total phenolic acids (Chotimah et al. 2007). Chotimah et al. (2013) revealed that application of carboxylic acid derivatives group increased $\mathrm{Al}$ root and $\mathrm{P}$ root accumulation, while at the top, carboxylic acid derivatives group decreased $\mathrm{Al}$ shoot Aloe vera. Peat water ameliorant application was able to lead to more efficient chalk usage for $75 \%$ in black soybean adaptation toward Al stress (Pujiwati et al. 2015). Mimmo et al. (2013) revealed that the release of organic acids plays an important role in alleviating $\mathrm{Al}$ toxicity. $A$. virginicus showed an Al-stress-induced synthesis and secretion of citrate and malate in roots, this mechanism may help to suppress an increase of toxic $\mathrm{Al}$ ions in the root region (Ezaki et al. 2013). Wang et al. (2012) revealed that construction of a new citrate synthesis pathway by simultaneous overexpression of CS and PEPC in the cytoplasm of transgenic plant leaves could enhance $\mathrm{Al}$ resistance in plants. Approximately $60-80 \%$ of synthesized organic acids were secreted to the medium by each plant, independent of Al stress (Ezaki et al. 2013).

Table 2. Effect of exogenous compounds on root length, plant height, number of leaves, diameter of stem, root dry weight, shoot dry weight of oil palm seedlings at 30 DAT

\begin{tabular}{|c|c|c|c|c|c|c|}
\hline \multirow{2}{*}{ Treatments } & \multirow{2}{*}{ RL (cm) } & \multirow{2}{*}{ PH (cm) } & \multirow{2}{*}{ NL } & \multirow{2}{*}{ DS (cm) } & \multicolumn{2}{|c|}{ Dry Weight (g) } \\
\hline & & & & & Roots & Shoots \\
\hline $0 \mathrm{Al}$ & $47.09 \mathrm{a}$ & $33.80 \mathrm{~b}$ & $6.33 \mathrm{a}$ & $1.80 \mathrm{a}$ & $1.08 \mathrm{ab}$ & $5.46 \mathrm{ab}$ \\
\hline $400 \mu \mathrm{M} \mathrm{Al}$ & $37.10 \mathrm{c}$ & $37.73 \mathrm{ab}$ & $6.33 \mathrm{a}$ & $1.80 \mathrm{a}$ & $0.88 \mathrm{~d}$ & $4.61 \mathrm{~cd}$ \\
\hline $\mathrm{Al}+\mathrm{Et} 25$ & $32.50 \mathrm{~d}$ & $36.50 \mathrm{ab}$ & $6.00 \mathrm{a}$ & $1.80 \mathrm{a}$ & $0.67 \mathrm{e}$ & $3.77 \mathrm{e}$ \\
\hline $\mathrm{Al}+\mathrm{Et} 50$ & $26.93 \mathrm{e}$ & $36.03 \mathrm{ab}$ & $6.00 \mathrm{a}$ & $1.83 \mathrm{a}$ & $0.64 \mathrm{e}$ & $3.81 \mathrm{e}$ \\
\hline $\mathrm{Al}+\mathrm{Et} 100$ & $18.74 \mathrm{f}$ & $33.60 \mathrm{~b}$ & $6.33 \mathrm{a}$ & $1.80 \mathrm{a}$ & $0.33 \mathrm{f}$ & $2.51 \mathrm{f}$ \\
\hline $\mathrm{Al}+\mathrm{CA} 25$ & $44.26 \mathrm{ab}$ & $35.43 \mathrm{ab}$ & $6.00 \mathrm{a}$ & $1.77 \mathrm{a}$ & $1.10 \mathrm{a}$ & $4.43 \mathrm{de}$ \\
\hline $\mathrm{Al}+\mathrm{CA} 50$ & $46.99 \mathrm{a}$ & $38.70 \mathrm{a}$ & $6.33 \mathrm{a}$ & $1.80 \mathrm{a}$ & $0.98 \mathrm{bc}$ & $4.58 \mathrm{~cd}$ \\
\hline $\mathrm{Al}+\mathrm{CA} 100$ & $40.02 \mathrm{bc}$ & $34.03 \mathrm{~b}$ & $6.00 \mathrm{a}$ & $1.77 \mathrm{a}$ & $0.89 \mathrm{~d}$ & $4.16 \mathrm{de}$ \\
\hline $\mathrm{Al}+\mathrm{PW} 100$ & $41.28 \mathrm{bc}$ & $35.77 \mathrm{ab}$ & $6.33 \mathrm{a}$ & $1.70 \mathrm{a}$ & $1.03 \mathrm{bc}$ & $5.16 b c$ \\
\hline $\mathrm{Al}+\mathrm{PW} 200$ & $47.80 \mathrm{a}$ & $36.60 \mathrm{ab}$ & $7.00 \mathrm{a}$ & $1.77 \mathrm{a}$ & $1.16 \mathrm{a}$ & $5.90 \mathrm{a}$ \\
\hline $\mathrm{Al}+\mathrm{PW} 300$ & $37.59 \mathrm{c}$ & $36.87 \mathrm{ab}$ & $7.00 \mathrm{a}$ & $1.87 \mathrm{a}$ & $1.08 \mathrm{ab}$ & $5.59 \mathrm{a}$ \\
\hline
\end{tabular}

Note: The numbers followed by the same letters in the same column show no significant difference based on DMRT at the level $\alpha: 5 \%$; DAT: day after treatment; RL: root length; PH: plant height; NL: number of leaves; DS: diameter of stem; Et: ethephon; CA: citric acid; PW: peat water 
Exposing seedlings of oil palm to high concentration of $\mathrm{Al}(400 \mathrm{uM})$ brought about a decrease of all physiological characters except carotenoids and anthocyanin (Tabel 3), the physiological characters of which were photosynthesis rate, chlorophyll a and chlorophyll b content at 30 DAT. Application of ethephon did not have a significant effect on photosynthesis rate, chlorophyll a and chlorophyll b content, and carotenoids, but it enhanced extremely anthocyanins more than three times. The results of this experiment have justified why ethylene was not able to increase the growth performance of seedlings under $\mathrm{Al}$ stress conditions (Table 2), it was clearly proven that ethylene actually reduced photosynthesis and both chlorophyll a and chlorophyll b content (Table 3). The increase of anthocyanin when ethylene was applied is an interesting phenomenon, as it is known that anthocyanin is a pigment that often increases when abiotic stress occurs. Ezaki et al. (2013) revealed that Al-induced synthesis of polyphenolic compounds including anthocyanin also occurred in roots as a long-term response to $\mathrm{Al}$ toxicity and anthocyanin production did not co-localize with either $\mathrm{Al}$ accumulation, nitric oxide (NO) production or lipid peroxides production in the roots. The concentration of the blue $\mathrm{Al}(3+)$-anthocyanin complex reached a maximum when a sufficient excess of aluminum was present (Schreiber et al. 2011).

Application of $200 \mathrm{ppm}$ peat water elevated the rate of photosynthesis, as well as content of chlorophyll a, chlorophyll b, and carotenoid. According to Panda et al. (2009), Al stress could reduce the content of chlorophyll, but giving exogenous compounds such as citric acid (Hu et al. 2016; Song et al. 2018) and humic acid (Mirdad, 2016) enabled seedlings to alleviate chlorophyll damage, thus improved the photosynthesis rate. Chotimah et al. (2007) explained that peat water contains $0.104 \%$ humic acid. This increase in photosynthetic rate is expected to be associated with the effect of the humic acid compound contained in peat water. There are other compounds that have the same effect, which able to act as antioxidants when plants are exposed to $\mathrm{Al}$ stress, i.e. carotenoids and anthocyanin (Apel and Hirt 2004; Sopandie 2014). Li et al. (2017) mentioned that ethephon was able to induce the synthesis of anthocyanin in root hairs which were thought to have important role in the mechanism of tolerance when plants were subjected to high concentration of $\mathrm{Al}$.

A high concentration of $\mathrm{Al}(400 \mathrm{uM})$ elevated tremendously MDA content compares with control at both 1 DAT and 3 DAT (Fig 2A). An increase in MDA levels in the tissue indicates that there has been damage due to lipid peroxidation of the membrane after exposurement of seedlings to high concentration of Al. Xu et al. (2012) pointed out that the addition of $\mathrm{Al}(3+)$ significantly increased MDA. Meanwhile, the activity of CAT (Fig. 2B) and APX (Fig. 2C) enzymes in the addition of Al was lower than that of the control, presumably, the plant's recovery ability was not able to compensate for cell damage. Nasr et al. (2011) pointed out that increasing $\mathrm{Al}$ concentration in root medium, APX activity was significantly decreased. Addition some exogenous compounds can reduce stress levels with different magnitudes as shown in Fig.2, the alleviating effect of $\mathrm{Al}$ stress was observed more clearly at 1 DAT as shown by lower accumulation of MDA at that time. The experimental results revealed that ethylene has a contribution to the response pathway of the signal transduction as shown that addition of 25 ppm ethylene has returned MDA levels back almost to their original level. There was a little effect of ethephon at concentrations of 50 and 100 ppm in reducing MDA levels at 1 DAT, their effect was not observed at 3 DAT, even MDA elevated much higher. These results corresponded to the increase in the activity of CAT (Fig 2B) and APX (Fig 2C) enzymes under the presence of ethylene at both 1 DAT and 3 DAT. Zhang et al. (2018) showed that ethephon treatment on tobacco plants increased the enzyme activity of APX, POD, and CAT under PEG-induced drought conditions.

Table 3. Effect of exogenous compound in photosynthesis rate, chlorophyll a, chlorophyll b, carotenoids and anthocyanin in oil palm seedlings at 30 DAT

\begin{tabular}{|c|c|c|c|c|c|}
\hline Treatments & $\begin{array}{c}\text { Photosynthesis } \\
\left(\mu \mathrm{mol} \mathrm{m}{ }^{-2} \mathrm{~s}^{-1}\right)\end{array}$ & $\begin{array}{c}\text { Chlorophyll a } \\
\left(\mathrm{mol} \mathrm{100} \mathrm{g}^{-1}\right)\end{array}$ & $\begin{array}{c}\text { Chlorophyll b } \\
\left(\mathrm{mol} \mathrm{100} \mathrm{g}^{-1}\right)\end{array}$ & $\begin{array}{l}\text { Carotenoids } \\
\left(\mathrm{mol} \mathrm{100}^{-1}\right) \\
\end{array}$ & $\begin{array}{c}\begin{array}{c}\text { Anthocyanin } \\
\left(\mathrm{mol} \mathrm{100} \mathrm{g}^{-1}\right)\end{array} \\
\end{array}$ \\
\hline $0 \mathrm{Al}$ & $6.34 \mathrm{bc}$ & $3.66 \mathrm{ab}$ & $1.14 \mathrm{ab}$ & $1.57 \mathrm{abcd}$ & $0.13 \mathrm{~d}$ \\
\hline $400 \mu \mathrm{M} \mathrm{Al}$ & $3.00 \mathrm{de}$ & $2.60 \mathrm{~b}$ & $0.84 \mathrm{~b}$ & $1.18 \mathrm{~d}$ & $0.23 \mathrm{~cd}$ \\
\hline $\mathrm{Al}+\mathrm{Et} 25 \mathrm{ppm}$ & $4.31 \mathrm{~cd}$ & $2.56 \mathrm{~b}$ & $0.91 \mathrm{~b}$ & $1.26 \mathrm{~cd}$ & $0.29 \mathrm{bc}$ \\
\hline $\mathrm{Al}+\mathrm{Et} 50 \mathrm{ppm}$ & $1.57 \mathrm{e}$ & $2.66 \mathrm{~b}$ & $0.93 \mathrm{~b}$ & $1.56 \mathrm{abcd}$ & $0.39 \mathrm{ab}$ \\
\hline $\mathrm{Al}+\mathrm{Et} 100 \mathrm{ppm}$ & $2.01 \mathrm{e}$ & $2.48 \mathrm{~b}$ & $0.85 \mathrm{~b}$ & $1.38 \mathrm{bcd}$ & $0.42 \mathrm{a}$ \\
\hline $\mathrm{Al}+\mathrm{CA} 25 \mathrm{ppm}$ & $8.78 \mathrm{a}$ & $4.53 \mathrm{a}$ & $1.50 \mathrm{a}$ & $2.00 \mathrm{a}$ & $0.28 \mathrm{bc}$ \\
\hline $\mathrm{Al}+\mathrm{CA} 50 \mathrm{ppm}$ & $6.08 \mathrm{bc}$ & $4.25 \mathrm{a}$ & $1.43 \mathrm{a}$ & $1.79 \mathrm{abc}$ & $0.19 \mathrm{~cd}$ \\
\hline $\mathrm{Al}+\mathrm{CA} 100 \mathrm{ppm}$ & $9.38 \mathrm{a}$ & $4.23 \mathrm{a}$ & $1.45 \mathrm{a}$ & $1.88 \mathrm{ab}$ & $0.16 \mathrm{~cd}$ \\
\hline $\mathrm{Al}+\mathrm{PW} 100 \mathrm{pm}$ & $5.44 \mathrm{c}$ & $2.57 \mathrm{~b}$ & $0.85 \mathrm{~b}$ & $1.25 \mathrm{~cd}$ & $0.18 \mathrm{~cd}$ \\
\hline $\mathrm{Al}+\mathrm{PW} 200$ ppm & $6.85 \mathrm{~b}$ & $4.25 \mathrm{a}$ & $1.40 \mathrm{a}$ & $1.83 \mathrm{abc}$ & $0.17 \mathrm{~cd}$ \\
\hline $\mathrm{Al}+\mathrm{PW} 300 \mathrm{ppm}$ & $5.98 \mathrm{bc}$ & $3.65 \mathrm{ab}$ & $1.15 \mathrm{ab}$ & $1.69 \mathrm{abcd}$ & $0.21 \mathrm{~cd}$ \\
\hline
\end{tabular}

Note: The numbers followed by the same letters in the same column show no significant difference based on DMRT at the level $\alpha: 5 \%$; DAT: day after treatment; Et: ethephon; CA: citric acid; PW: peat water 

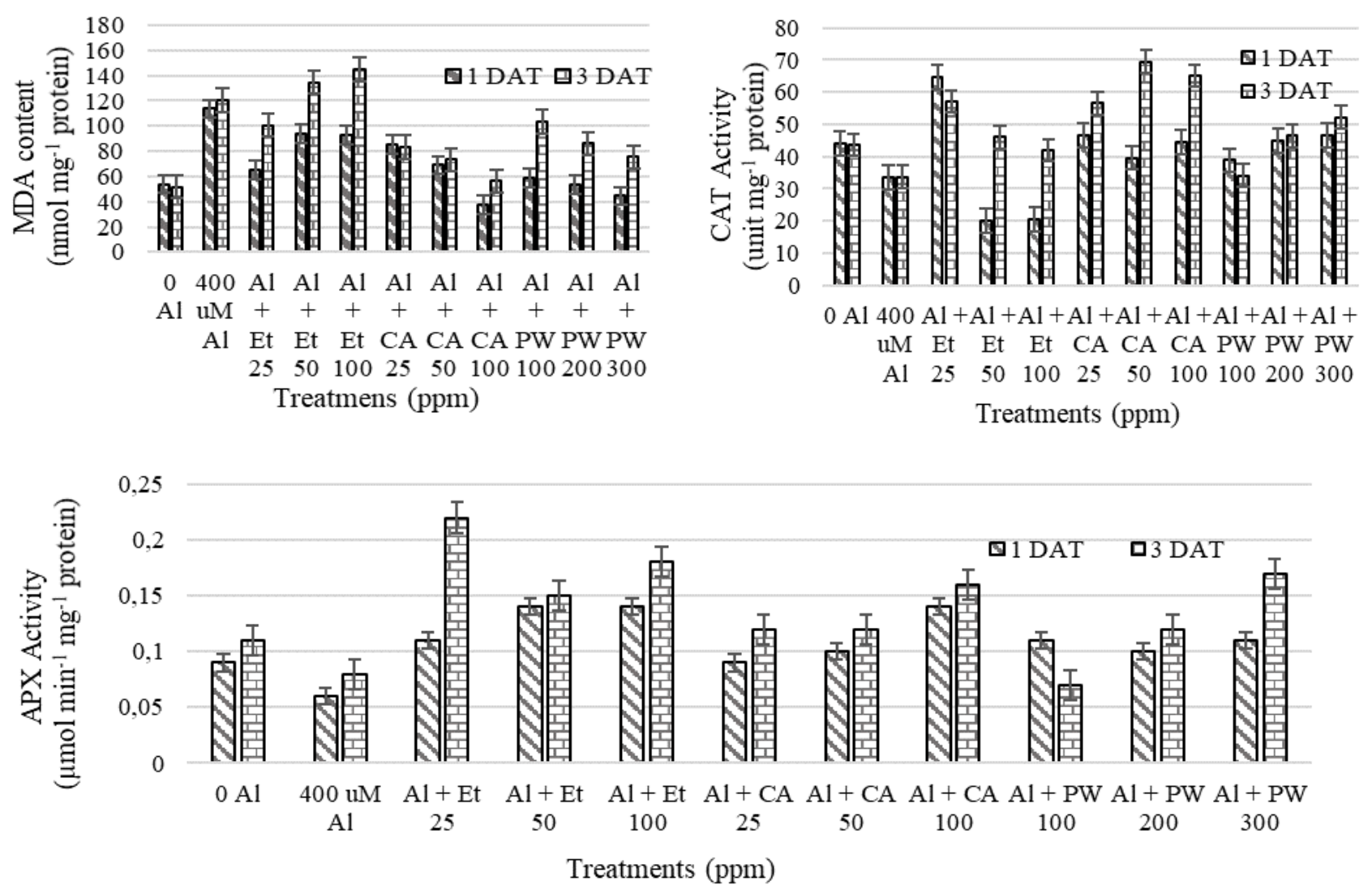

Figure 2. The effect of application of exogenous substances on MDA content (A), CAT (B) and APX activities (C); DAT = day after treatment; $\mathrm{Et}=$ ethephon; $\mathrm{CA}=$ citric acid; $\mathrm{PW}=$ peat water. The bars represent the standard error of the mean

Citric acid appears to be more effective in reducing MDA levels, especially at concentrations of $100 \mathrm{ppm}$ at 1 DAT and 3 DAT (Figure 2.A). There was an increase in CAT activity (Figure 2.B) and APX (Figure 2.C) when the oil palm seedlings were added with citric acid at 1 DAT and 3 DAT. This fact can answer the relationship between citric acid application with decreased MDA levels and increased activity of CAT and APX enzymes as well as increased tolerance of seeds to Al side effects (Table 2). The application of citric acid can increase the activity of CAT and APX enzymes which play a role in ROS scavenging so that MDA accumulation is reduced drastically. Hongyu et al. (2018) showed that after giving exogenous citric acid, the activity of antioxidant enzymes in the leaves increased, and the content of $\mathrm{H} 2 \mathrm{O} 2$, MDA, and osmotic regulatory substances in the leaves decreased. Similar results were also seen in the addition of $200 \mathrm{ppm}$ or $300 \mathrm{ppm}$ of peat water which was able to reduce MDA levels. The addition of $200 \mathrm{ppm}$ and $300 \mathrm{ppm}$ of peat water also increased the enzyme activity of CAT (Fig. 2B) and APX (Fig. 2C). These results related to the increased activity of CAT and APX enzymes with the addition of peat water which indicates the involvement of peat water in the signal transduction response. This response is thought to play a role in the humic acid contained in peat water. Zykova et al. (2018) revealed that all humic acid fractions from peat showed antioxidant activity in radical scavenging. Application of humic acid under stress reduces $\mathrm{H} 2 \mathrm{O} 2$ levels through activation of superoxide dismutase (SOD) and CAT (Yildiztugay et al. 2019). The addition of citric acid and peat water exogenously was able to increase the tolerance of oil palm seedlings to $\mathrm{Al}$ stress, as indicated by the increase in root length, root dry weight, photosynthesis rate, chlorophyll content, activity of CAT and APX enzymes, and decreased levels of MDA.

\section{ACKNOWLEDGEMENTS}

The authors would like to thank the PT Astra Agro Lestari, Tbk., Indonesia for all of the supports.

\section{REFERENCES}

Apel K, Hirt H. 2004. Reactive oxygen species: metabolism, oxidative stress, and signal transduction. Annu Rev Plant Biol 55: 373-399. DOI: 10.1146/annurev.arplant.55.031903.141701.

Chen T, Zang B. 2016. Measurements of proline and malondialdehyde contents and antioxidant enzyme activities in leaves of droughtstressed cotton. Bio-protocol 6 (17): e1913. www.bioprotocol.org/e1913.

Chotimah HENC, Yahya S, Ghulamahdi M, Sabiham S. 2007. Sifat-sifat kimia, kompensasi dan kadar asam organik gambut dan air gambut kelurahan Bereng Bengkel, Kalimantan Tengah. Anterior J. 7 (1): 1-9. 
Chotimah HENC, Yahya S, Ghulamahdi M, Sabiham S. 2013. Aluminuminduced physiological responses of Aloe vera grown in the presence of phenolic and carboxylic acid derivated. J AGRIPEAT 14 (2): 7077

Corley RHV, Tinker PBH. 2015. The Oil Palm Fifth Ed. Blackwell Science Ltd. West Sussex.

Cristancho RJA, Hanafi MM, Omar SRS, Rafii MY. 2011. Variations in oil palm (Elaeis guineensis Jacq.) progeny response to high aluminum concentration in solution culture. Plant Biol 13 (2): 333-342. DOI 10.1111/j.1438-8677.2010.00378.x

Delhaize E, Ryan PR. 1995. Aluminum toxicity and tolerance in plants. Plant Physiol. 107:315-321.

Direktorat Perbenihan Perkebunan. 2020. Daftar Varietas Unggul Komoditi Kelapa Sawit in: Aplikasi eBenih Tanaman Perkebunan. Direktorat Jenderal Perkebunan. Kementerian Pertanian Indonesia. http://aplikasi2.pertanian.go.id/ebenihbun/lap_komo_varietas.php.

Ezaki B, Jayaram K, Higashi A, Takahashi K. 2013. A combination of five mechanisms confers a high tolerance for aluminum to a wild species of Poaceae, Andropogon virginicus L. Environ Exp Bot 93 35-44. DOI: 10.1016/j.envexpbot.2013.05.002.

Hongyu Y, Yamin L, Shengnan Z, Yumin L, Wenying Z, Zhenzhen W. 2018. Effects of exogenous citric acid on physiological characteristics of Pinus massoniana under aluminum stress. Scientia Silvae Sinicae. 54 (7): 155-164.

Hu L, Zhang Z, Xiang Z, Yang Z. 2016. Exogenous application of citric acid ameliorates the adverse effect of heat stress in Tall fescue (Lolium arundinaceum). Front Plant Sci 7:179. DOI: 10.3389/fpls.2016.00179.

Jiang H-X, Chen L-S, Zheng J-G, Han S, Tang N, Smith B. 2009. Aluminum-induced effects on Photosystem II photochemistry in Citrus leaves assessed by the chlorophyll a fluorescence transient Tree Physiol 28 (12): 1863-71. DOI: 10.1093/treephys/28.12.1863.

Kopittke PM. 2016. Role of phytohormones in aluminum rhizotoxicity. Plant Cell Environ. 39 (10): 2319-2328. DOI: 10.1111/pce.12786.

Kusvuran S, Kiran S, Ellialtioglu SS. 2016. Antioxidant enzyme activities and abiotic stress tolerance relationship in vegetable crops. http://www.IntechOpen.com.

Levitt J. 1980. Response of Plants to Environmental Stress. Academic Press, New York

Li X, Thwe AA, Park CH, Kim SJ, Arasu MV, Al-Dhabi NA, Lee SY, Park SU. 2017. Ethephon-induced phenylpropanoid accumulation and related gene expression in tartary buckwheat (Fagopyrum tataricum (L.) Gaertn.) hairy root. Biotechnol Biotechnol Equip 31 (2): 304 311. DOI: $10.1080 / 13102818.2017 .1282835$

Li YY, Zhang YJ, Zhou Y, et al. 2009. Protecting cell walls from binding aluminum by organic acids contributes to aluminum resistance. J Integr Plant Biol $51 \quad$ (6): 574-580. DOI: 10.1111/j.17447909.2009.00825 x

Lubis AU. 2008. Kelapa sawit (Elaeis guineensis Jacq.) di Indonesia (Oil Palm (Elaeis guineensis Jacq.) in Indonesia). Indonesian Oil Palm Research Institute, Medan. [Indonesian].

Marlina, Hasmeda M, Hayati R, Priadi DP. 2017. Keragaan morfofisiologi tanaman kelapa sawit di lahan gambut. Jurnal Littri 23 (2): 98-104. DOI: 10.21082/littri. v23n2.2017.98 - 104. [Indonesian]

Mendez YDR, Chacón AM, Romero HM. 2014. Response of the roots of oil palm $\mathrm{O} \times \mathrm{G}$ interspecific hybrids (Elaeis oleifera $\times$ Elaeis guineensis) to aluminum (Al3+) toxicity. AJCS. 8(11): 1526-1533.

Miller G, Suzuki N, Ciftci-Yilmaz S, Mittler R. 2010. Reactive oxygen species homeostasis and signalling during drought and salinity stresses. Plant Cell Environ 33: 453-467. DOI: 10.1111/j.1365 3040.2009.02041.x.

Mimmo T, Ghizzi M, Cesco S, Tomasi N, Pinton R, Puschenreiter M. 2013. Aluminium-phosphate interactions in the rhizosphere of two bean species: Phaseolus lunatus L. and Phaseolus vulgaris L. J. Sci. Food Agric 93, 3891-3896. http://dx.doi.org/10.1002/jsfa.6392.

Mirdad ZM. 2016. Effect of $\mathrm{N}$ fertigation rates and humic acid on the productivity of crisphead lettuce (Lactuca sativa L.) grown in sandy soil. J Agric Sci 8 (8). DOI:10.5539/jas.v8n8p149

Nakano, Asada. 1981. Hydrogen peroxide is scavenged by ascorbatespecific peroxidase in spinach chloroplasts. Plant Cell Physiol. 22 (5) 867-880.

Onaga G, Wydra K. 2016. Advances in plant tolerance to abiotic stresses. In: Abdurakhmonov IY (eds). Plant Genomics. DOI: 10.5772/64350.

Panda SK, Baluska F, Matsumoto H. 2009. Aluminum stress signaling in plants. Plant Signal Behav 4 (7): 592-597.
Proklamasiningsih E, Prijambada ID, Rachmawati D, Sancayaningsih RP. 2012. Pengaruh pemberian garam aluminum (Al) terhadap serapan $\mathrm{Al}$ dan pertumbuhan akar kedelai pada media tanam masam. Bionatura 14 (2): 107- 114. [Indonesian]

Pujiwati H, Ghulamahdi M, Yahya S, Aziz SA, Haridjaja O. 2015. Efisiensi pengapuran dengan amelioran air gambut memperbaiki adaptasi kedelai hitam (Glycine soja) terhadap cekaman $\mathrm{Al}$ dan $\mathrm{Fe}$ di lahan pasang surut. Dalam S. Herlinda, Suwandi, Tanbiyaskur, D. Nursyamsi, M. Noor, S. Anwar (eds.). Prosiding Seminar Nasional Lahan Suboptimal 2015. Palembang, 8-9 Oktober 2015.

Ratnasari S, Putra ETS, Dewa DI. 2016. Analysis of the growth of oil palm (Elaeis guineensis Jacq.) exposed by aluminum toxicity and silica as an amelioration. Jurnal Ilmu Pertanian (Agricultural Science) 2 (1): 015-019. DOI: 10.22146/ipas. 11194

Ritung S, Suryani E, Subardja D, Sukarman, Nugroho K, Suparto, Hikmatullah, Mulyani A, Tafakresnanto C, Sulaeman Y, et al. 2015. Sumber daya lahan pertanian Indonesia: luas, penyebaran dan potensi ketersediaan. IAARD Press, Jakarta. [Indonesian].

Rout GR, Samantaray S, Das P. 2001. Aluminum toxicity in plants: a review. Agronomie 21: 2-21. DOI: 10.1051/agro:2001105.

Sadak MS, Orabi SA. 2015. Improving thermotolerance of wheat plant by foliar application of citric acid or oxalic acid. Int.J. Chem Tech Res 8 (1): 333-345

Schreiber H, Jones A, Lariviere C, Mayhew K, Cain J. 2011. Role of aluminum in red-to-blue color changes in Hydrangea macrophylla sepals. BioMetals. 24. 1005-15. DOI: 10.1007/s10534-011-9458-x.

Setiawan K. 2017. Pemuliaan Kelapa Sawit; Untuk Produksi Benih Unggul: Tanaman Pendek, Kompak, dan Minyak Tak Jenuh Tinggi. Plantaxia, Yogyakarta. [Indonesian].

Shahnawaz, Sanadhya. 2017. Aluminium induced oxidative stress and antioxidant system in two barley varieties and its alleviation through ascorbic acid and salicylic acid seed priming approach. Int. J. Life Sci. Pharma Res. 7 (3): 26-37.

Sharma A, Kumar V, Sidhu GPS, Kumar R, Kohli S, Yadav P, Kapoor D, Bali A, Shahzad B, Khanna K, Kumar S, Thukral A, Bhardwaj R. 2019. Abiotic stress management in plants: roles of ethylene. In: A Roychoudhury, D K Tripathi (eds) Molecular Plant Abiotic Stress: Biology and Biotechnology, 1 ed. John Wiley \& Sons Ltd. West Sussex.

Sim DA, Gamon JA. 2002. Relationship between leaf pigment content and spectral reflectance across a wide range of species leaf structures and development stages. Remote Sens Environ 81: 337-354. DOI: 10.1016/S0034-4257(02)00010-X

Song JF, Markewitz D, Wu S, Sang Y, Duan C, Cui XY. 2018. Exogenous oxalic acid and citric acid improve lead $(\mathrm{Pb})$ tolerance of Larix olgensis A. Henry seedlings. Forests 9 (510). DOI: $10.3390 / \mathrm{f} 9090510$

Sopandie D. 1990. Studies on Plant Responses to Salt Stress. [Disertation]. Okayama University, Okayama, Japan.

Sopandie D. 2014. Fisiologi Adaptasi Tanaman terhadap Cekaman Abiotik pada Agroekosistem Tropika (Physiological Adaptation of Plants to Abiotic Stress in Tropical Agroecosystem). IPB Press, Bogor, Indonesian.

Sun L, Tian J, Zhang H, Liao H. 2016. Phytohormone regulation of root growth triggered by $\mathrm{P}$ deficiency or Al toxicity. J Exp Bot 67 (12): 3655-3664. DOI: $10.1093 / \mathrm{jxb} / \mathrm{erw} 188$.

Supena N, Soegianto A, Soetopo L. 2014. Response of oil palm varieties to aluminum stress. J Trop Life Sci 4 (1): 51-60.

Wang Q, Yi Q, Hu Q, Zhao Y, Nian H, Li K, Yu Y, Izui K, Chen L. 2012. Simultaneous overexpression of citrate synthase and phosphoenolpyruvate carboxylase in leaves augments citrate exclusion and al resistance in transgenic tobacco. Plant Mol Biol Rep 30 (4): 992-1005

Xu FJ, Li G, Jin CW, Liu WJ, Zhang SS, Zhang YS, Lin XY. 2012. Aluminum-induced changes in reactive oxygen species accumulation, lipid peroxidation and antioxidant capacity in wheat root tips. Biol Plant 56: 89-96

Yamamoto Y, Kobayashi Y, Matsumoto H. 2001. Lipid peroxidation is an early symptom triggered by aluminum, but not the primary cause of elongation inhibition in pea roots. Plant Physiol. 125: 199-208. DOI: 10.1104/pp.125.1.199

Yang LL. 2014. Influence of exogenous calcium on several physiological indices of pepper plant under aluminum stress. J. Anhui Agric. Univ. 25: 8481-8482,8485.

Yang M, Tan L, Xu Y, Zhao Y, Cheng F, Ye S, Jiang W. 2015. Effect of low $\mathrm{pH}$ and aluminum toxicity on the photosynthetic characteristics 
of different fast-growing Eucalyptus vegetatively propagated clones. PloS one 10(6): e0130963. DOI: 10.1371/journal.pone.0130963

Yu J, Niu L, Yu J, Liao W, Xie J, Lv J, Feng Z, Hu L, Dawuda MM. 2019. The involvement of ethylene in calcium-induced adventitious root formation in cucumber under salt stress. Int. J. Mol. Sci. 20 (5): 1047. DOI: $10.3390 /$ ijms 20051047

Yildiztugay E, Ozfidan-Konakci C, Elbasan F, Yildiztugay A, Kucukoduk M. 2019. Humic acid protects against oxidative damage induced by cadmium toxicity in wheat (Triticum aestivum) roots through water management and the antioxidant defense system. Botanica Serbica 43 (2): 161-173. DOI: 10.2298/BOTSERB1902161Y
Zhang N, Han L, Xu L, Zhang X. 2018. Ethephon seed treatment impacts on drought tolerance of Kentucky bluegrass seedlings. HortTechnology 28:319-326. DOI: 10.21273/HORTTECH03976-18.

Zhao MG, Tian QY, Zhang WH. 2007. Ethylene activates a plasma membrane $\mathrm{Ca}(2+)$-permeable channel in tobacco suspension cells. New Phytol 174(3): 507-515. DOI: 10.1111/j.14698137.2007.02037.x

Zykova MV, Schepetkin IA, Belousov MV, Krivoshchekov SV, Logvinova LA, Bratishko KA, Yusubov MS, Romanenko SV, Quinn MT. 2018. Physicochemical characterization and antioxidant activity of humic acids isolated from peat of various origins. Molecules 23 (4): 753. DOI: 10.3390/molecules23040753. 